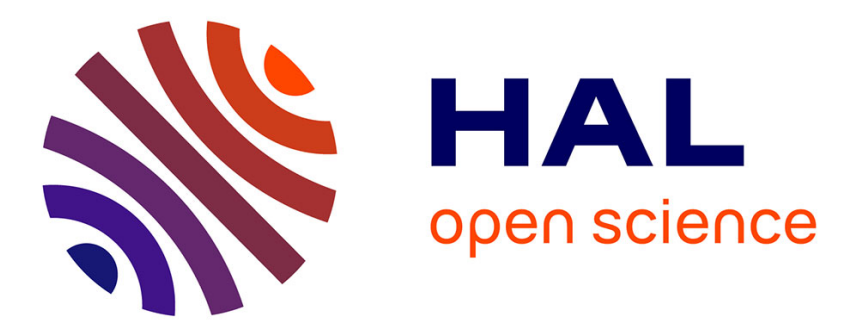

\title{
Breakdown of the Yr17 resistance to yellow rust of wheat in northern Europe
}

\author{
Rosemary Bayles, Kerstin Flath, Mogens Hovmøller, Claude de \\ Vallavieille-Pope
}

\section{To cite this version:}

Rosemary Bayles, Kerstin Flath, Mogens Hovmøller, Claude de Vallavieille-Pope. Breakdown of the Yr17 resistance to yellow rust of wheat in northern Europe. Agronomie, 2000, 20 (7), pp.805-811. 10.1051/agro:2000176 . hal-00886077

\section{HAL Id: hal-00886077 https://hal.science/hal-00886077}

Submitted on 1 Jan 2000

HAL is a multi-disciplinary open access archive for the deposit and dissemination of scientific research documents, whether they are published or not. The documents may come from teaching and research institutions in France or abroad, or from public or private research centers.
L'archive ouverte pluridisciplinaire HAL, est destinée au dépôt et à la diffusion de documents scientifiques de niveau recherche, publiés ou non, émanant des établissements d'enseignement et de recherche français ou étrangers, des laboratoires publics ou privés. 


\title{
Breakdown of the $\mathrm{Yr} 17$ resistance to yellow rust of wheat in northern Europe
}

\author{
Rosemary A. BAYLES ${ }^{a *}$, Kerstin Flath ${ }^{b}$, Mogens S. HovMøLLER ${ }^{c}$, \\ Claude de VALlaVieILle-POPE ${ }^{\mathrm{d}}$
}

\author{
${ }^{a}$ National Institute of Agricultural Botany, Cambridge, CB3 OLE, UK \\ ${ }^{\mathrm{b}}$ Federal Biological Research Centre for Agriculture and Forestry, Institute for Plant Protection of Field Crops and Grassland, \\ 14532 Kleinmachnow, Germany \\ ${ }^{\mathrm{c}}$ Danish Institute of Agricultural Sciences, Flakkebjerg, 4200 Slagelse, Denmark \\ ${ }^{\mathrm{d}}$ INRA, Laboratoire de Pathologie Végétale et Epidémiologie, BP 01, 78850 Thiverval-Grignon, France
}

(Received 13 April 2000; revised 11 June 2000; accepted 29 June 2000)

\begin{abstract}
The gene Yr17, conferring resistance to Puccinia striiformis f.sp.tritici, was introduced into northern European wheat cultivars in the mid 1970s. Virulence for $\operatorname{Yr} 17$ was not detected until 1994, when it was identified in the UK and Denmark. In both countries, susceptible $\mathrm{Yrl7}$ cultivars were grown on an increasingly large area over the next four years and this was followed by a rise in the frequency of corresponding virulence to $100 \%$. Elsewhere in northern Europe $\mathrm{Yr} 17$ cultivars were grown on a relatively small scale during this period. However, virulence for $\mathrm{Yr} 17$ was detected in France and Germany in 1997 and reached a frequency in excess of 70\% by 1999, suggesting an influx of pathogen spores from UK or Denmark. Migration of pathogen spores around northern Europe clearly plays an important role in determining the virulence composition of local populations of Puccinia striiformis $\mathrm{f}$. sp. tritici. It is vital that this should be reflected in cooperation between national virulence monitoring projects.
\end{abstract}

\section{Puccinia / yellow rust / virulence / wheat / resistance}

Résumé - Contournement du gène de résistance Yr17 à la rouille jaune du blé en Europe du Nord. Le gène de résistance Yrl7 vis-à-vis de Puccinia striiformis f. sp. tritici, agent de la rouille jaune du blé, a été introduit dans les cultivars Nord-Européens à partir de 1975. La virulence correspondante n'a été détectée qu'en 1994 en Angleterre et au Danemark. Dans ces deux pays, la superficie des terres emblavées par des cultivars portant $Y r 17$ et sensibles à la rouille jaune a augmenté de 1994 à 1997 et est restée très importante jusqu'en 1998. La virulence vis-à-vis de $\mathrm{Yr} 17$ a atteint $100 \%$. Dans les autres pays du Nord de l'Europe, les cultivars Yr17 sensibles à la rouille jaune ont été cultivés sur de petites surfaces. Toutefois la virulence vis-à-vis de Yrl7 a été détectée en France et en Allemagne en 1997 avec une

Communicated by Rients E. Niks (Wageningen, The Netherlands)

* Correspondence and reprints

rosemary.bayles@niab.com 
fréquence de plus de $70 \%$ en 1999, suggérant une migration des spores du parasite à partir de l'Angleterre ou du Danemark. La migration des spores joue un rôle déterminant dans la composition des populations locales de $P$. striiformis f. sp. tritici. Il est impératif que des projets de coopération de suivi des virulences soient coordonnés à l'échelle européenne.

Puccinia / rouille jaune / virulence / blé / résistance

\section{Introduction}

Yellow rust of wheat, caused by the fungus Puccinia striiformis Westend. f. sp. tritici, is a major cause of yield loss in wheat crops worldwide. In Europe, the disease is most common in a region spanning northern France, the Netherlands, northern Germany, Denmark and UK. However, in some years yellow rust becomes more significant further south. Typically, epidemics occur when large areas of potentially susceptible wheat cultivars are grown and pathotypes of yellow rust adapted to these cultivars are widespread. Pathotype frequencies in populations of $P$. striiformis f. sp. tritici may differ between geographical regions or countries and respond rapidly to the resistance genes exploited locally by farmers and plant breeders. With an increasing trend for plant breeding to be conducted on a European scale, cultivars, or the resistances in them, are common to several countries. At the same time, the pathogen is able to spread for long distances by airborne uredospores, without regard to national boundaries, probably leading to a large degree of interaction between the yellow rust populations of northern Europe.

National surveys of pathogen virulence have been carried out, with varying regularity, in individual European countries for many years. These surveys are valuable individually, but are potentially of far greater benefit if they can be integrated to encompass a much larger geographical area. At its simplest, the detection of 'breakdown' of a resistance in one part of Europe can be regarded as an early warning in regions where the resistance is still effective.

The main objective of the yellow rust sub-group of WG1 (Surveys of Virulence and Aggressive- ness) of COST Action 817, was to achieve comparability of the results of national surveys so that yellow rust populations can be monitored across Europe. Initially, the main barrier to amalgamating virulence data from national surveys was variation between the differential sets used in different countries. Some national surveys adhered to the 'World and European' series of differentials as proposed by Johnson et al. [11] whilst others, such as UK, had formulated their own series of differentials with particular relevance for the breeding programmes in their own countries. The first task of the yellow rust sub-group was therefore to agree on a set of differentials to meet the needs of European workers. This agreed set is shown in Table I and is intended as a 'core' set, to be used by all collaborators

Table I. Core set of differential cultivars for identifying virulence for yellow rust resistance genes - COST 817 .

\begin{tabular}{ll}
\hline Differential cultivar & Gene \\
\hline Chinese 166 & $\operatorname{Yr} 1$ \\
Kalyansona & $\operatorname{Yr} 2$ \\
Vilmorin 23 & $\operatorname{Yr} 3$ \\
Nord Desprez & $\operatorname{Yr} 3$ \\
Hybrid 46 & $\operatorname{Yr} 6, \operatorname{Yr} 2$ \\
Heines Peko & $\operatorname{Yr} 6, \operatorname{Yr} 2$ \\
Heines Kolben & $\operatorname{Yr} 7$ \\
Lee & $\operatorname{Yr} 7+$ \\
Reichersberg 42 & $\operatorname{Yr} 9$ \\
Compair & $\operatorname{Yr} 10$ \\
Kavkaz $\times 4$ Federation & $\operatorname{Yr} 15$ \\
Moro & $\operatorname{Yr} 17$ \\
Yr15/6*AvS & $\mathrm{CV}$ \\
VPM 1 & $\operatorname{YrA}$ \\
Carstens V & $\mathrm{Su}$ \\
Avocet 'R' & $\mathrm{SD}$ \\
Suwon 92 $\times$ Omar & $\mathrm{SPA}$ \\
Strubes Dickkopf & \\
Spaldings Prolific &
\end{tabular}


across Europe and to be augmented locally to meet particular national requirements. Over the period of the Action, sub-group members gradually adopted the core set of differentials, drawing on authentic seed stocks where there was any doubt about the identity or purity of local stocks. It was not the intention to impose a standard system of pathotype nomenclature, as it was recognised that the differential set might need to be reviewed again after a few years of practical experience or if more suitable differentials, such as near-isogenic lines, became available.

Progress towards the group's aim of integrating virulence surveys across Europe is discussed in this paper, taking as an example the emergence of virulence for the $\mathrm{Yr} 17$ resistance gene. $\mathrm{Yrll}$ is a gene derived from Triticum ventricosum, from which it was transferred to the hexaploid wheat line VPM1 [7,12]. The gene is located on chromosome 2AS [1]. Although the primary aim of breeders had been to transfer eyespot resistance to bread wheat, resistance to the rust diseases was also achieved. Amongst the first $\operatorname{Yr} 17$ cultivars to reach commercialisation were the French cultivars Roazon, registered in 1976, Pernel in 1983 and Renan in 1989. Pernel, the most widely grown of these, reached $5-7 \%$ of the wheat acreage in France between 1987 and 1988. In UK, the cultivar Rendezvous was officially recommended in 1987, but was never widely grown. There were no reports of virulence for $\operatorname{Yr} 17$ in Europe until 1994, when virulence was detected for the first time in both the UK [3] and Denmark (Hovmøller, unpublished ). In the years that followed, epidemics of yellow rust were witnessed in both countries on Yrl7 cultivars and virulence for $\mathrm{Yr} 17$ became more widely distributed across northern Europe $[8,10$, 14].

\section{Materials and methods}

Yellow rust virulence surveys were conducted throughout the period 1993-1999 in Denmark, France, Germany and UK. The common aim of these surveys was to study the race structure and evolution of the pathogen population [2]. Other principle aims were the early detection of new pathotypes and the provision of information and inoculum to plant breeders and official variety testing organisations.

Pathotypes were identified by the traditional approach of determining the virulence or avirulence of test isolates on a set of differential cultivars with known resistance genes or resistance sources. Procedures for collecting samples and testing isolates were broadly similar in all countries. Samples of infected leaves were collected from cultivar trials, breeders' plots and commercial crops, with particular attention usually being focused on previously resistant cultivars. Isolates established from individual stripes, or from a small number of stripes, were subsequently multiplied on seedlings of a susceptible genotype to provide adequate inoculum for storage and differential tests. Seedlings of differential cultivars were inoculated either when the first leaf was fully emerged or slightly later when the second leaf was partially emerged. Inoculation was either by dry spores, with or without talc as a carrier, or by oil-based spore suspensions. Dry spores were applied either by blowing or by use of a settling tower. Spore suspensions were applied as a spray. All methods provided a critical period of between 24 and 48 hours at $100 \%$ relative humidity immediately after inoculation. This was achieved by placing seedlings in sealed containers at around $7-8{ }^{\circ} \mathrm{C}$. Subsequent incubation was either in the glasshouse or in controlled environment chambers with temperature and lighting regimes which differed slightly between countries. Minimum temperatures were in the range $11{ }^{\circ} \mathrm{C}$ to $16{ }^{\circ} \mathrm{C}$ and maxima in the range $17{ }^{\circ} \mathrm{C}$ to $20^{\circ} \mathrm{C}$. $16-18 \mathrm{~h}$ light periods were provided.

Seedling responses were normally assessed 10-18 days after inoculation, using qualitative infection type classes, either on a $0-9$ scale [13] or 0-4 scale [9]. Compatible interactions, (host susceptibility, pathogen virulence) were defined as infection types 7,8 and 9 on the $0-9$ scale and 3 and 4 on the $0-4$ scale. All other infection types were defined as incompatible interactions (host resistance, pathogen avirulence). 


\section{Results}

Figures $1 \mathrm{a}$ and $1 \mathrm{~b}$ show the percentage of the wheat acreage sown with $\mathrm{YrIT}$ cultivars and the frequency of the corresponding virulence in Denmark, France, Germany and UK between 1993 and 1999.

In 1993, $\operatorname{Yr} 17$ cultivars reached around $1 \%$ of the wheat acreage in Denmark and UK and between $2 \%$ and 5\% in France. No Yr17 cultivars
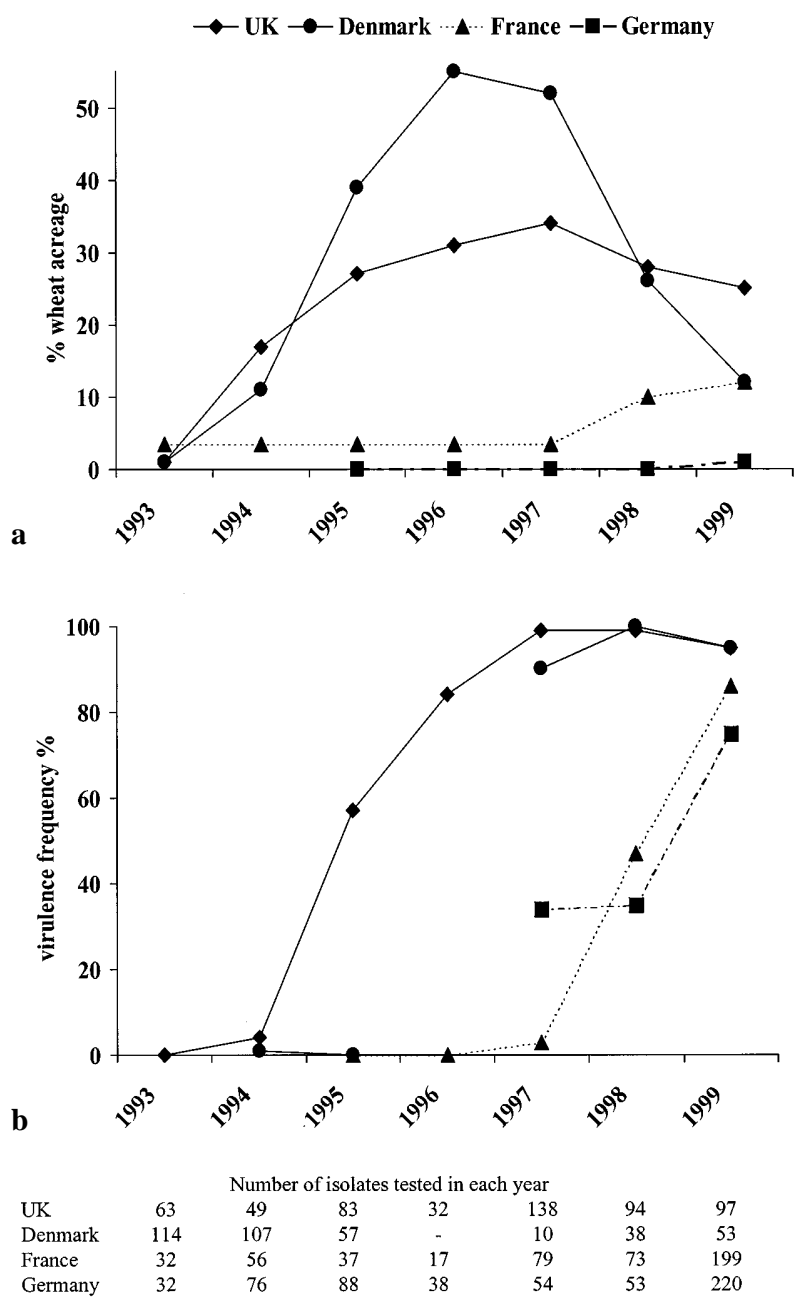

Figure 1. a. Percentage of national wheat acreages growing Yrl7 cultivars in Denmark, France, Germany and UK between 1993 and 1999. b. Frequency of virulence for $\mathrm{Yr} 17$ in populations of $P$. striiformis f. sp. tritici in Denmark, France, Germany and UK between 1993 and 1999. were being grown commercially in Germany. There was no evidence of virulence for $Y r 17$ in any of these countries at this stage and the cultivars concerned were completely resistant to yellow rust in the field. Between 1994 and 1997 there was a steep rise in the acreage of $\mathrm{Yrl} 17$ cultivars in Denmark and UK, peaking at around $55 \%$ in Denmark in 1996 and 35\% in UK in 1997. The predominant $\mathrm{Yrl7}$ cultivar in Denmark was Hussar, which has a greater degree of partial resistance than its highly susceptible sister line Brigadier, which dominated the $\operatorname{Yr} 17$ acreage in UK. Virulence for $\operatorname{Yr} 17$ was first detected in the UK and Denmark in 1994. Over the next three years it built up to nearly $100 \%$ frequency in UK. In Denmark, no further $\mathrm{Yr} 17$-virulent isolates were identified in 1995, and in 1996 no yellow rust was detected under natural conditions, so that no samples could be collected. However, in 1997 and 1998 virulence for $\operatorname{Yr} 17$ jumped to the same high level as in the UK.

In France, $\operatorname{Yr} 17$ cultivars remained at less than $5 \%$ of the acreage until 1998, when they increased to $10 \%$, reaching $12 \%$ in 1999 . However, half of this acreage was of cultivars possessing additional resistance genes, making them resistant to existing Yrl7-virulent pathotypes (Doussinault and Dredryver, pers. comm.). In Germany, $\operatorname{Yr} 17$ cultivars made a negligible contribution to the wheat acreage throughout the entire seven year period, although several $\mathrm{Yr} 17$ cultivars were undergoing multiplication, or being grown on a small scale, in 1999 (Flath, pers. comm.). Despite the relatively low selection pressure from $\mathrm{Yr} 17$ cultivars in France and Germany, virulence was detected in both countries in 1997 and reached frequencies of over $70 \%$ by 1999 .

The most common yellow rust pathotypes identified in 1999 are shown in Table II. This classification of pathotypes takes into account virulence for those resistances tested in all four countries. Pathotype a (virulent on $\mathrm{Yrl}, \mathrm{Yr} 2, \mathrm{Yr} 3, \mathrm{Yr} 4, \mathrm{Yr}$, $\operatorname{Yr17}, \mathrm{Su}, \mathrm{SD})$ was the predominant pathotype in all countries. Pathotypes with combined virulence for $\operatorname{Yr} 17$ with $\operatorname{Yr} 6$ were present in $\mathrm{UK}$ and Denmark (pathotypes $\mathrm{c}$ and $\mathrm{d}$ in UK and pathotype c in Denmark). Pathotype e, similar to pathotype a 
Table II. Frequency of the most common pathotypes of P. striiformis f. sp. tritici in 1999.

\begin{tabular}{|c|c|c|c|c|c|c|}
\hline & \multicolumn{6}{|c|}{ Pathotype } \\
\hline & $\mathrm{a}$ & $\mathrm{b}$ & $\mathrm{c}$ & $\mathrm{d}$ & $\mathrm{e}$ & $\mathrm{f}$ \\
\hline $\operatorname{Yr} 1$ & $\mathrm{~V}$ & $\mathrm{~V}$ & $\mathrm{~V}$ & $\mathrm{~V}$ & $\mathrm{~V}$ & \\
\hline $\operatorname{Yr} 2$ & $\mathrm{~V}$ & V & $\mathrm{V}$ & $\mathrm{V}$ & $\mathrm{V}$ & V \\
\hline $\operatorname{Yr} 3$ & $\mathrm{~V}$ & $\mathrm{~V}$ & $\mathrm{~V}$ & $\mathrm{~V}$ & $\mathrm{~V}$ & \\
\hline $\operatorname{Yr} 4$ & $\mathrm{~V}$ & & $\mathrm{~V}$ & $\mathrm{~V}$ & $\mathrm{~V}$ & \\
\hline $\operatorname{Yr} 6$ & & & $\mathrm{~V}$ & $\mathrm{~V}$ & & V \\
\hline $\operatorname{Yr} 7$ & & & & $\mathrm{~V}$ & & \\
\hline $\operatorname{Yr} 8$ & & & & & & V \\
\hline $\operatorname{Yr} 9$ & $\mathrm{~V}$ & $\mathrm{~V}$ & $\mathrm{~V}$ & $\mathrm{~V}$ & $\mathrm{~V}$ & \\
\hline $\operatorname{Yr} 17$ & $\mathrm{~V}$ & $\mathrm{~V}$ & $\mathrm{~V}$ & $\mathrm{~V}$ & $\mathrm{~V}$ & \\
\hline $\mathrm{CV}$ & & & & & $\mathrm{V}$ & \\
\hline $\mathrm{Su}$ & $\mathrm{V}$ & & $\mathrm{V}$ & $\mathrm{V}$ & $\mathrm{V}$ & \\
\hline SD & $\mathrm{V}$ & $\mathrm{V}$ & $\mathrm{V}$ & $\mathrm{V}$ & $\mathrm{V}$ & \\
\hline \multicolumn{7}{|l|}{ SPA } \\
\hline & \multicolumn{6}{|c|}{$\%$ isolates } \\
\hline Denmark & 62 & 25 & 9 & & & \\
\hline France & 81 & 5 & & & & 14 \\
\hline Germany & 27 & & & & 12 & \\
\hline UK & 51 & 5 & 15 & 9 & & \\
\hline
\end{tabular}

$\mathrm{V}=$ virulent blank = avirulent.

but virulent on $\mathrm{CV}$, was identified in Germany, but not in the other coutries. Only in southern France was a pathotype without virulence for $\mathrm{Yr} 17$ significant (pathotype $\mathrm{f}$ with virulence for $\mathrm{Yr} 2, \mathrm{Yr} 6, \mathrm{Yr} 8$ ).

\section{Discussion}

During the seven years from 1993 to 1999 , there were clear distinctions between the countries of northern Europe with respect to the exposure of the yellow rust resistance $\mathrm{Yrl} 7 \mathrm{in}$ wheat cultivars and the frequency of corresponding virulence in the pathogen population. Wheat cultivars with $\mathrm{Yrl7}$ resistance first became popular in UK and Denmark in 1993/1994 and over the next few years increased rapidly to around $35 \%$ of the UK acreage and $55 \%$ of the acreage in Denmark. In France and Germany, the acreage of cultivars with the $\mathrm{Yrl}$ resistance was more limited throughout most of the period. In the UK and Denmark, virulence for $\mathrm{Yr} 17$ increased with the increase in the $Y r 17$ cultivars, following the well-known pattern of response of pathogen virulence to host resistance [6]. There was a lag between the build up of virulence in the UK and in Denmark. This may be due in part to differences in the background resistance of the Yrl7 cultivars being grown in the two countries at the time. In UK, the predominant cultivar was the highly susceptible Brigadier, which had the lowest possible rating of 1 for resistance to yellow rust on the UK Recommended List of Varieties. In Denmark the main cultivar was Hussar, with a moderate rating of 5 on the same list. This would tend to result in relatively severe epidemics on Yr17 cultivars in UK, encouraging a more rapid increase in virulence.

Whether virulence for $\mathrm{Yr} 17$ arose as independent events in the two countries, or whether virulent pathotypes spread from UK to Denmark, has so far been a matter of speculation. A recent study using molecular markers showed that migration between UK and Denmark was sufficiently frequent to prevent divergence of the yellow rust populations in the two countries and isolates of the same pathotype often shared Amplified Fragment Length Polymorphism fragments (Hovmøller, unpublished). The abrupt rise, to nearly $100 \%$, in frequency of virulence for $\operatorname{Yr} 17$ in Denmark in 1997 , is certainly consistent with immigration of Yr17-virulent spores from UK. There is evidence from DNA studies of high degrees of similarity between certain UK and Danish isolates of the same pathotype, suggesting migration of clones between the two countries (Hovmøller, unpublished). For France and Germany, where there was little cultivar-related selection for the $\mathrm{Yrl7}$-virulent pathotypes found there, spread from elsewhere seems the most likely explanation. The predominance of a single pathotype across northern Europe also lends support to this theory. The complexity of pathotypes possessing virulence for $\mathrm{Yr} 17$ would have enabled them to establish and increase on a wide range of non-Yr17 cultivars.

All isolates carrying virulence for $\mathrm{Yr} 17$ were also virulent to $\operatorname{Yr} 9$ (Tab. II). This is not surprising, 
since $\operatorname{Yr} 9$ has been widely exploited in European wheat cultivars, with the result that the corresponding virulence has been at a high level since the late 1980s [5]. In addition, many Yrl7 cultivars also carry $\mathrm{Yr}$ 9. These include Brigadier and Hussar, the most widely grown $\mathrm{Yrll}$ cultivars at the time virulence was first detected.

Combined virulence for $\mathrm{YrIT}$ with $\mathrm{Yr} 6$ was detected only in UK (pathotypes c, d) and Denmark (pathotype c). The combination of these two resistances is found in cultivars such as Equinox, Madrigal and Lynx [4] and Yr6 may still be protecting the resistance of other $Y r 17$ cultivars in countries where pathotypes with this virulence combination have not yet been detected. Given the likelihood of migration of spores between countries, there is a strong possibility that this virulence combination will be identified in France and Germany within the next year or so.

Among the pathotypes lacking virulence for Yrl7 was pathotype $\mathrm{f}$, which was identified in southern France. Previous experience has shown that pathotypes encountered in the south of that country are usually quite different from those found in the north, suggesting only a low degree of interchange between populations of yellow rust in the north and south of France (de VallavieillePope, pers. comm.). Epidemics are less common in the south than in the north and the spectrum of cultivars grown is usually different. Pathotypes found in southern France are more likely to be related to those in Spain and North Africa that regularly carry virulence for $\mathrm{Yr} 8$, which is uncommon in north-western Europe.

Although a virulence survey has not been carried out routinely in the Netherlands in recent years, virulence for $\mathrm{Yr} 17$ has been confirmed there (G.H.J. Kema, pers. comm.), completing the picture across northern Europe.

The rise and fall of the $\mathrm{Yr} 17$ resistance in Europe underlines the dangers of single gene deployment. It also emphasises the importance of monitoring populations of airborne pathogens on an international scale. Within northern Europe, the emergence of a new virulence in one country is likely to be closely followed by its appearance in others. The time-scale not only depends on the geographical distance and direction of prevailing air currents, but also on the extent to which the critical resistance is exploited in different countries and on the genetic backgrounds in which it is exposed. Changes in virulence in one country act as an early warning to plant breeders in other countries, allowing them to adapt their breeding strategies to take account of the new situation, before, rather than after, a problem occurs. In practice, such warnings have probably had less impact than they might have done because of the widespread use of cost effective fungicides in northern Europe. However, with increasing economic and political pressures to reduce chemical inputs in wheat production, plant breeders will need to respond by putting greater emphasis on disease resistance Well organised national virulence surveys provide the basis for wider collaboration in support of European plant breeding programmes. The challenge for the future will be to maintain and build upon the initiatives established as part of COST 817 and high priority should continue to be given to the integration of virulence survey data throughout Europe.

Acknowledgments: The authors are grateful for the invaluable contributions made by all other members of the yellow rust sub-group of COST Action 817: Ole Andersen, Lesley Boyd, Claudio Ciccarone, Renata Hanusova, Roy Johnson, Gert Kema, Diego Rubiales Olmedo, Cor van Silfhout, Otto Unger, Ursula Walther, Michael Winzeler.

\section{References}

[1] Bariana H., McIntosh R., Characterization and origin of rust and powdery mildew resistance genes in VPM1 wheat, Euphytica 76 (1994) 53-61.

[2] Bayles R.A., Subgroup 3: Yellow rust of wheat and barley. COST 817, Population studies of airborne pathogens on cereals as a means of improving strategies for disease control, Annu. Rep. for 1995, 1997, pp. 67-80.

[3] Bayles R.A., Stigwood P.L., Yellow rust of wheat. UK Cereal Pathogen Virulence Survey, Annu. Rep. for 1995, 1996, pp. 13-17. 
[4] Bayles R.A., Stigwood P.L., Yellow rust of wheat. UK Cereal Pathogen Virulence Survey, Annu. Rep. for 1996, 1997, pp. 13-17.

[5] Bayles R.A., Channell M.H., Stigwood P.L., Yellow rust of wheat. UK Cereal Pathogen Virulence Survey, Annu. Rep. for 1989, 1990, pp. 11-17.

[6] Bayles R.A., Clarkson J.D.S., Slater S.E., The UK Cereal Pathogen Virulence Survey, in: Crute I.R., Holub E.B., Burdon J.J. (Eds.), The Gene for Gene Relationship in Plant - Parasite Interactions, CAB International, Wallingford, Oxon, UK, 1997, pp. 103-118.

[7] Doussinault G., Dosba F., Jahier J., Use of a hybrid between Triticum aestivum L. and Aegilops ventricosa Tausch in wheat breeding, in: Miller T.E, Koebner R.M.D. (Eds.), Proceedings of the Seventh International Wheat Genetics Symposium. Institute of Plant Science Research, Cambridge, UK, 1998, pp. 253-258.

[8] Flath K., Bartels G., 1999 - ein Gelbrostbefallsjahr. Ausblick und Folgerungen. Vortr. Pflanzenz. 46 (1999) 145-156.

[9] Gassner G., Straib W., Die bestimmung der biologischen rassen des weizengelbrostes (Puccinia glumaium f. sp. tritici (Schmidt.) Erikss. und Henn.),
Arb. Biol. Reichsanst. Land Forstw. (Berlin) 20 (1932) 141-163.

[10] Hovmøller M.S., Epidemiologi og resistens mod gulrust i hvede. DJF report No. 10 [16th Danish Plant Protection Conference, Pests and Diseases], 1999, pp. 119-127. Danmarks Jordbrugsforskning, Foulum (1999).

[11] Johnson R., Stubbs R.W., Fuchs E., Chamberlain N.H., Nomenclature for physiologic races of Puccinia striiformis infecting wheat, Trans. Br. Mycol. Soc. 58 (1972) 475-480.

[12] Maia N., Obtention de blés tendres résistants au piétin-verse (Cercosporella herpotrichoides) par croisements interspécifiques, C. R. Acad. Sci. Fr. 53 (1967) 149-154.

[13] McNeal F.H., Konzak C.F., Smith E.P., Tate W.S., Russell T.S.A., Uniform System for Recording and Processing Cereal Research Data. Agricultural Research Service Bulletin 34-112, United States Department of Agriculture: Washington, 1971.

[14] de Vallavieille-Pope C., Leconte M., Mistou M.N., Delos M., Rouzet J., La rouille jaune du blé en France : des épidémies déclenchées par une nouvelle race, un hiver doux et un printemps humide, Phytoma (2000) (in press). 